\title{
REVIEW
}

\section{Transcription factors and asthma}

\author{
P.J Barnes I.M Adcock
}

Transcription factors and asthma. P.J Barnes I.M Adcock. OERS Journals Ltd 1998. ABSTRACT: Asthma is characterized by the expression of multiple genes for inflammatory proteins, such as cytokines, enzymes, receptors and adhesion molecules. This is orchestrated by transcription factors, which are proteins that bind to the promoter regions of these genes and may be activated by inflammatory stimuli, such as cytokines. Several transcription factors are involved in asthmatic inflammation, including nuclear factor- $\kappa \mathrm{B}(\mathrm{NF}-\kappa \mathrm{B})$, activator protein-1 (AP-1), nuclear factor of activated T-cells (NF-AT), cyclic AMP response element binding protein (CREB) and signal transduction-activated transcription factors (STAT). These transcription factors lead to coordinated expression of multiple inflammatory genes. There is increasing evidence that synergistic interaction of these transcription factors $(e . g$. NF- $\kappa \mathrm{B}$ and AP-1) results in the optimal expression of particular genes, resulting in the specific inflammatory pattern seen in asthmatic airways. Transcription factors are a target for antiasthma therapy. Corticosteroids activate glucocorticoid receptors, which themselves are transcription factors, and interact with other transcription factors to inhibit their actions. The interaction between transcription factors may be important in amplifying and inhibiting the inflammatory process. Many transcription factors interact with a large co-activator molecule CREB-binding protein (CBP) that coordinates the activation of several transcription factors and controls transcription through the regulation of deoxyribonucleic acid coiling around histone residues in the chromatin structure. Understanding transcription factors in asthma has given new insights into the complex chronic inflammatory process, the mechansm of action of corticosteroids, and may lead to new approaches to therapy in the future.

Eur Respir J 1998; 12: 221-234.
Dept of Thoracic Medicine, National Heart and Lung Institute, Imperial College, London, UK.

Correspondence: P.J. Barnes

Dept of Thoracic Medicine

National Heart and Lung Institute

Dovehouse St

London SW3 6LY

UK

Fax: 441713515675

Keywords: Activator protein-1

asthma

gene transcription

glucocorticoids

nuclear factor- $\mathrm{KB}$

transcription factors

Received: January 151998

Accepted after revision January 161998
In asthma, there is an increased expression of many proteins involved in the complex inflammatory cascade. These inflammatory proteins include cytokines, inflammatory enzymes, receptors and adhesion molecules. The increased expression of most of these proteins is the result of increased gene transcription; many of the genes are not expressed in normal cells but are induced in asthma. Changes in gene transcription are regulated by transcription factors, which are proteins that bind to deoxyribonucleic acid (DNA). This suggests that transcription factors may play a key role in the pathophysiology of asthma, since they regulate the increased gene expression that may underlie the acute and chronic inflammatory mechanisms that characterize the disease. Glucocorticoids are the most effective therapy in the long-term control of asthma and appear to reduce inflammation in asthmatic airways largely by inhibiting the transcription factors that regulate abnormal gene expression.

\section{Transcription factors}

Transcription factors are proteins that bind to regulatory sequences, usually in the 5 ' upstream promoter region of target genes, to increase (or sometimes decrease) the rate of gene transcription. This may result increased or decreased protein synthesis and altered cellular function.
Transcription factors may be activated by many extracellular influences acting via surface receptors that lead to phosphorylation by several types of kinase $[1,2]$, or may be directly activated by ligands (such as corticosteroids, thyroid hormone and vitamins). Transcription factors may therefore convert transient environmental signals at the cell surface into long-term changes in gene transcription, thus acting as "nuclear messengers" [3]. Transcription factors may be activated within the nucleus, often with the transcription factor already bound to DNA, or within the cytoplasm, resulting in exposure of nuclear localization signals and targeting to the nucleus. Thus transcription factors convert environmental signals into altered gene expression. In the context of inflammatory diseases, transcription factors activated by inflammatory stimuli (such as cytokines or viruses) switch on inflammatory genes, leading to increased synthesis of inflammatory proteins (fig. 1). In this way, transcription factors may amplify and perpetuate the inflammatory process, and this makes them an important potential target in the development of new anti-inflammatory drugs for asthma. It is possible that abnormal functioning of transcription factors may determine disease severity and responsiveness to treatment [4]. Of particular importance is the demonstration that transcription factors may physically interact with each other, resulting in inhibition or enhancement of transcriptional activity. 


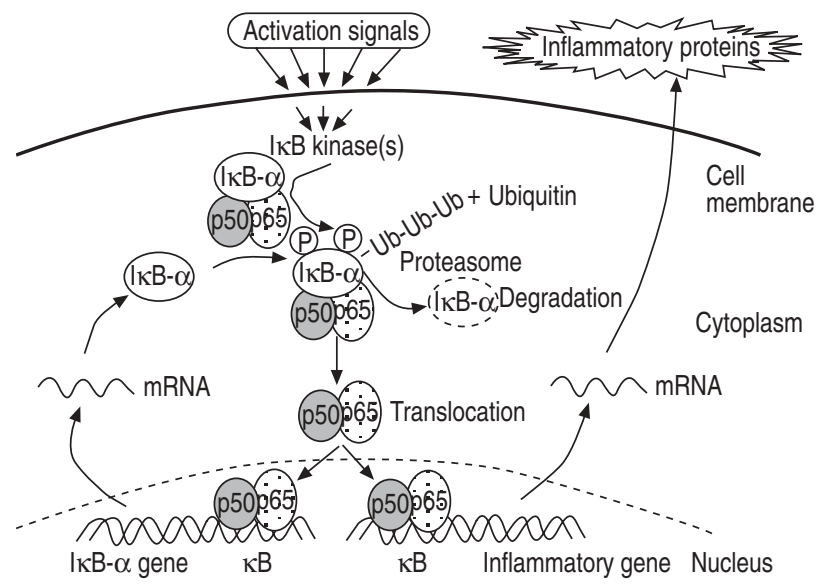

Fig. 1. - Activation of nuclear factor (NF)- $\kappa B$ involves phosphorylation of the inhibitory protein I $\kappa$ B by specific kinase(s), with subsequent ubiquitination and proteolytic degradation by the proteasome. The free $\mathrm{NF}-\kappa \mathrm{B}$ then translocates to the nucleus, where it binds to $\kappa \mathrm{B}$ sites in the promoter regions of inflammatory genes. Activation of the I $\mathrm{BB} \alpha$ gene results in increased synthesis of IKB $\alpha$ to terminate the activation of NF$\kappa \mathrm{B}$. mRNA: messenger ribonucleic acid.

\section{Transcription factor families}

Several families of transcription factors exist, and the members of each family may share structural characteristics. These families include helix-turn-helix (e.g. Oct-1), zinc finger (e.g. glucocorticoid receptors), basic proteinleucine zipper (cyclic AMP response element binding factor (CREB), nuclear factor- $\mathrm{\kappa B}(\mathrm{NF}-\kappa \mathrm{B})$, activator protein-1 (AP-1)) and $\beta$-sheet motifs (e.g. HU) [5]. Many transcription factors are common to several cell types (ubiquitous), whereas others are cell specific and determine the phenotypic characteristics of a cell.

\section{Methods for studying transcription factors}

There is relatively little information about the regulation of transcription factors in the airways, particularly in diseases such as asthma. However, molecular methods have been developed for the investigation of transcription factor expression and activity. These methods include immunoblotting and immunocytochemistry to detect the transcription factor protein, electrophoretic mobility shift assays to measure transcription factor binding to DNA and DNA footprinting to determine binding to recognition sequences in particular genes. Many transcription factors have now been discovered, but we will concentrate on some of the transcription factors that may be relevant in asthma. In the future, the genetic control of transcription factor expression may be an increasingly important aspect of research, as this may be one of the critical mechanisms regulating expression of asthma phenotypes and their responsiveness to therapy.

\section{Transcription factor interactions}

One of the most important concepts to have emerged is that transcription factors may interact with other transcription factors. This then allows cross-talk between different signal transduction pathways at the level of gene expression [6]. Indeed, it is the interaction of transcription factors that may give them different properties in different cell types, as the presence of other transcription factors will profoundly influence the effect exerted by a particular factor on gene expression. Interaction between transcription factors is particularly relevant to the action of drugs, such as corticosteroids and cyclosporin $\mathrm{A}$, which activate or block transcription factors that subsequently modulate other transcription factors.

\section{Basal transcription machinery}

Binding of transcription factors to their specific recognition sequences, or activation of the already bound transcription factors in the control regions (promoters) of target genes is communicated to the basal transcription machinery bound to the TATA box near the start site of transcription. This then leads to activation of the critical enzyme ribonucleic acid (RNA) polymerase II, via a chain of basal factors, resulting in increased transcription of the gene and formation of messenger RNA (mRNA), which in turn is then translated into a protein. Binding of transcription factors to their specific binding motifs in the promoter region may alter transcription by interacting directly with components of the basal transcription apparatus or via cofactors that link the transcription factor to the basal transcription apparatus [7]. Since DNA loops around histone residues, binding of a transcription factor even far from the TATA box may still allow it to interact.

Large proteins that bind to the basal transcription machinery may interact with many transcription factors and thus act as integrators of gene transcription. These co-activator molecules include CREB-binding protein (CBP), which was first recognized as a protein that the transcription factor CREB had to bind to in order to exert its effects [8]. Other co-activator molecules include p300, and these co-activators may bind multiple transcription factors, thus allowing complex interactions between different signalling pathways.

\section{Specific and ubiquitous transcription factors}

Many transcription factors have now been identified and a large proportion of the genome appears to code for these proteins. Many transcription factors are cell-specific and are responsible for the selective expression of genes that characterize a particular cell in terms of its structural characteristics, differentiation or function. One example of a specific transcription factor is the nuclear factor of activated T-cells (NF-AT) that regulates the expression of the lymphocyte proliferative factor interleukin (IL)-2 in T-lymphocytes. Many transcription factors, such as AP-1 and NF- $\mathrm{NB}$, are ubiquitous and regulate large sets of genes, so that a coordinated cellular response is produced. There may also be important interactions between transcription factors, so that it is necessary to have coincident activation of several transcription factors in order to obtain maximal gene expression. For example, IL-8 is regulated by NF- $\kappa B$ and CAAT/enhancer binding protein $(\mathrm{C} / \mathrm{EBP}) \beta$ (formerly nuclear factor of IL-6). C/EBP $\beta$ binding alone has little effect on IL-6 transcription but markedly enhances the effect of NF- $\kappa B$ binding, resulting in maximal gene expression [9]. This means that IL-8 will only be maximally transcribed when both transcription factors are activated simultaneously by coincident activating signals. These sorts 
of interaction explain how transcription factors that are ubiquitous may regulate particular genes in certain types of cell.

\section{Nuclear factor- $\kappa B$}

$\mathrm{NF}-\kappa \mathrm{B}$ is a ubiquitous transcription factor that appears to be of particular importance in inflammatory and immune responses. There is increasing evidence that NF- $\kappa \mathrm{B}$ plays a pivotal role in orchestrating the inflammatory response and acts as an amplifying and perpetuating mechanism [10]. NF- $\kappa \mathrm{B}$ was first identified as a regulator of immunoglobulin $\kappa$ light chain gene expression in murine B-lymphocytes [11], but has subsequently been identified in most cell types. NF- $\kappa \mathrm{B}$ binds to the $\kappa \mathrm{B}$ DNA sequence 5'-GGGACTTTCC-3'. Several different NF- $\kappa B$ proteins have been characterized and belong to the Rel family that share a 300 amino acid region known as the Rel homology domain that contains the DNA binding elements [12, 13]. The activated form of NF- $\kappa \mathrm{B}$ is a heterodimer, which usually consists of two subunits, p65 (RelA) and p50, although other forms such as Rel, RelB, v-Rel, p52, p105 $(\mathrm{NF}-\kappa \mathrm{B} 1)$ and p100 (NF- $\kappa \mathrm{B} 2)$ may also occur. P50 may be constitutively bound to DNA but requires p65 for transactivational activity. Rel proteins have been identified even in invertebrates, such Drosophila, where they play an important role in both development and primitive inflammatory responses. Targeted disruption of the genes coding for p65 or p50 in mice ("knock-outs") results in severe immune deficiency which is lethal in the case of p65 [14, $15]$.

\section{Activation of $N F-\kappa B$}

In unstimulated cells, NF- $\kappa \mathrm{B}$ is localized to the cytoplasm because of binding to inhibitory proteins (I $\kappa \mathrm{B})$, of which several isoforms exist (I $\kappa \mathrm{B}-\alpha, \mathrm{I} \kappa \mathrm{B}-\beta, \mathrm{I} \kappa \mathrm{B}-\gamma, \mathrm{I} \kappa \mathrm{B}-\delta$, I $\kappa \mathrm{B}-\varepsilon)$, the most abundant being IкB- $\alpha[16,17]$. When the cell is appropriately stimulated, specific I $\mathrm{KB}$ kinases phosphorylate $\mathrm{I} \kappa \mathrm{B}$, leading to the rapid addition of ubiquitin residues (ubiquitination) which make it a substrate for the proteasome, a multifunctional cellular protease $[18,19]$ (fig. 1). A specific IкB- $\alpha$ kinase complex (IKK) has now been identified and contains at least two interacting subunits [20]. Several signal transduction pathways are in-volved in the activation of NF- $\mathrm{BB}$ and enzymes from the mitogen-activated protein (MAP) kinase pathways may interact at various points in the activation of NF- $\kappa B$ [21]. A newly described kinase, NF- $\kappa B$ inducing kinase (NIK), is a MAP3K-related enzyme involved in the activation of IKK by tumour necrosis factor (TNF)- $\alpha$ and IL-1 $\beta$ [22]. A key enzyme in the stress-activated MAP kinase pathway that leads to the activation of c-Jun N-terminal kinase (JNK) is MEKK1, which also activates the $\mathrm{I} \kappa \mathrm{B}-\alpha$ kinase complex, indicating that mechanisms that activate JNK and AP-1, may also activate NF- $\kappa B$ [23].

Degradation of I $\kappa \mathrm{B}$ uncovers nuclear localisation signals on p65 and p50, so it is rapidly transported into the nucleus where it binds to specific $\mathrm{\kappa B}$ recognition elements in the promoter regions of target genes. The I $\mathrm{KB}-\alpha$ gene (MAD-3) itself has several $\kappa \mathrm{B}$ sequences in its promoter region, so that NF- $\kappa B$ induces the synthesis of $I \kappa B-\alpha$, which enters the nucleus to bind NF- $\mathrm{BB}$ and induce its export to the cytoplasm, thus terminating activation [24]. Newly synthesised IKB- $\alpha$ interacts with, and binds to NF$\kappa \mathrm{B}$ heterodimers within the cytoplasm and to NF- $\kappa \mathrm{B}$ bound to $\kappa \mathrm{B}$ sites within the nucleus [25]. Targeted disruption of the I $\kappa \mathrm{B}-\alpha$ gene results in prolonged activation of NF- $\kappa \mathrm{B}$ and the animals die of inflammation [26]. By contrast, I $\kappa \mathrm{B}-\beta$ is not induced by NF- $\kappa \mathrm{B}$, so NF- $\kappa \mathrm{B}$ is likely to be activated for a more prolonged period in cell types in which IкB- $\beta$ predominates [27].

Many stimuli activate NF- $\kappa B$, including the cytokines IL- $1 \beta$, TNF- $\alpha$, IL-2 and granulocyte-macrophage colonystimulating factor (GM-CSF) [12], oxidative stress (particularly hydrogen peroxide) [28], viruses (such as rhinovirus and adenovirus) [29], phorbol esters, lipopolysaccharide (LPS) and B- and T-lymphocyte activation. Several signal transduction pathways may be involved in this activation, but all of these stimuli appear to act via rapidly activated protein kinases that lead to I $\kappa$ B phosphorylation. The activation of these protein kinases may be blocked by antioxidants, such as pyrrolidine dithiocarbamate (PDTC) and $\mathrm{N}$-acetyl cysteine, suggesting that reactive oxygen species may act as intermediary molecules in NF- $\kappa \mathrm{B}$ activation in response to a wide range of stimuli [30].

\section{Inflammatory and immune genes}

$\mathrm{NF}-\kappa \mathrm{B}$ is now known to regulate the expression of many inflammatory and immune genes. Many of these genes are induced in inflammatory and structural cells and play an important role in the inflammatory process. Whereas, NF- $\kappa \mathrm{B}$ is not the only transcription factor involved in regulation of the expression of these genes, it often appears to have a decisive regulatory role. $N F-\kappa B$ often functions in cooperation with other transcription factors, such as AP-1 and C/EBP, that are also involved in regulation of inflammatory and immune genes [9, 31]. Genes induced by NF- $\kappa \mathrm{B}$ include those for the proinflammatory cytokines IL-1 $\beta$, TNF- $\alpha$, and GM-CSF and the chemokines IL-8, macrophage inflammatory protein (MIP)-1 $\alpha$, macrophage chemotactic protein-1 (MCP-1), "Regulated on activation, normal T-cell expressed and secreted" (RANTES) and eotaxin, that are largely responsible for attracting inflammatory cells into sites of inflammation [12, 32-35]. $\mathrm{NF}-\kappa \mathrm{B}$ also regulates the expression of inflammatory enzymes, including the inducible form of nitric oxide synthase (iNOS) that produces large amounts of NO [36] and inducible cyclo-oxygenase (COX-2) that produces prostanoids $[37,38]$. NF- $\kappa \mathrm{B}$ also plays an important role in regulating expression of adhesion molecules, such as Eselectin, vascular cell adhesion molecule-1 (VCAM-1) and intercellular adhesion molecule-1 (ICAM-1), that are expressed on endothelial and epithelial cells at inflammatory sites and play a key role in the initial recruitment of inflammatory cells $[39,40]$. This suggests that activation of NF- $\mathrm{KB}$ leads to the coordinated induction of multiple genes that are expressed in inflammatory and immune responses.

Products of genes that are regulated by $\mathrm{NF}-\kappa \mathrm{B}$ also cause its activation. Thus, the proinflammatory cytokines IL- $1 \beta$ and TNF- $\alpha$ both activate, and are activated by, NF$\kappa \mathrm{B}$; this may result in a positive regulatory loop that may be important in amplifying and perpetuating the inflammatory response at the local site (fig. 2). 


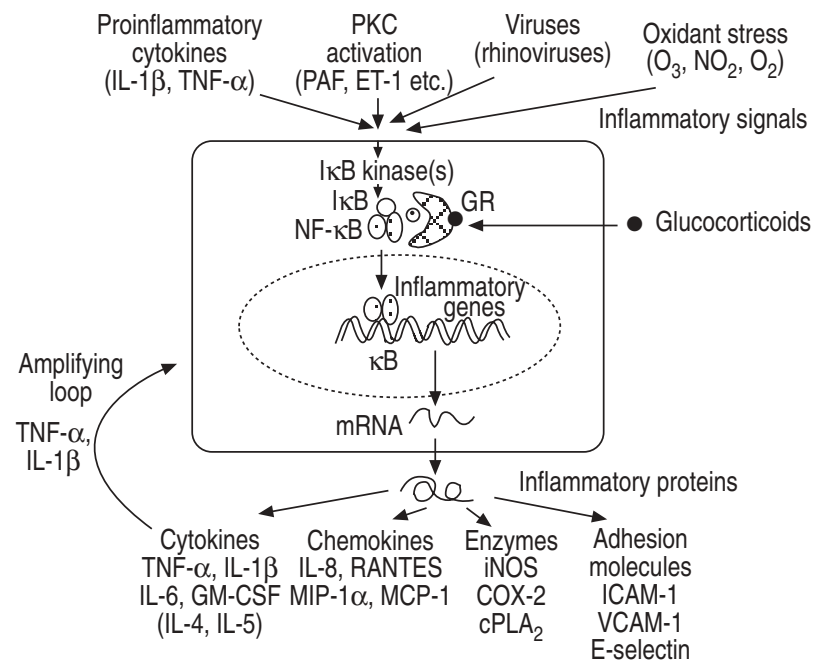

Fig. 2. - Nuclear factor (NF)- $\kappa B$ may be activated by a variety of inflammatory signals, resulting in the coordinated expression of multiple inflammatory genes, including cytokines, chemokines, enzymes and adhesion molecules. The cytokines interleukin (IL)-1 $\beta$ and tumour necrosis factor (TNF)- $\alpha$ both activate and are regulated by NF- $\kappa \mathrm{B}$ and may there act as an amplifying feed forward loop. The actions of NF- $\kappa B$ are inhibited by glucocorticoids via activation of glucocorticoid receptors (GR). PKC: protein kinase C; GM-CSF: granulocyte-macrophage colony-stimulating factor; RANTES: "regulated on activation, normal T-cell expressed and secreted" chemokine; MIP: macrophage inflammatory protein; MCO: macrophage chemotactic protein; iNOS: inducable sum of nitrogen oxide synthesis; COX: cyclo-oxygenase; $\mathrm{CPLA}_{2}$ : cytosolic phospholipase $\mathrm{A}_{2}$; ICAM-1: intercellular adhesion molecule1; VCAM-1: vascular cell adhesion molecule-1.

$\mathrm{NF}-\kappa \mathrm{B}$ also plays a complex role in apoptosis. Inhibition of NF- $\kappa \mathrm{B}$ increases apoptosis in response to TNF- $\alpha$ in several cell types, including lymphocytes, suggesting that NF- $\kappa \mathrm{B}$ counteracts apoptosis $[41,42]$.

\section{Role in asthma}

$\mathrm{NF}-\kappa \mathrm{B}$ may be activated by many of the stimuli that exacerbate asthmatic inflammation. In experimental animals, allergen exposure in sensitized animals activates NF- $\kappa \mathrm{B}$ in the lung [43] with concomitant expression of iNOS and chemokines [44]. In animal studies, in vivo activation of T- lymphocytes with CD3 antibodies results in marked activation of NF- $\kappa B$ [45]. Oxidants activate NF- $\kappa B$ in a human epithelial lines, resulting in increased expression of iNOS [46] and exposure of animals to the oxidant ozone results in NF- $\kappa \mathrm{B}$ expression in lung [47]. Exposure of human peripheral blood mononuclear cells, epithelial cells and lung tissue to proinflammatory cytokines results in a marked activation of $\mathrm{NF}-\kappa \mathrm{B}$ that may be prolonged [48-50]. Virus infections are common triggers of acute severe exacerbations of asthma and are thought to initiate a prolonged inflammatory response. Thus, experimental rhinovirus infection results in the activation of NF- $\kappa \mathrm{B}$ and IL-6 secretion in nasal epithelial cells [29]. Viruses may activate NF- $\kappa \mathrm{B}$ through mechanisms that involve generation of reactive oxygen intermediates [28]. There is also evidence for activation of NF- $\mathrm{KB}$ in biopsies of patients with asthma and in inflammatory cells in the sputum [51].

Many of the inflammatory and immunoregulatory genes (cytokines, enzymes, adhesion molecules) expressed in asthma are regulated predominantly by NF- $\mathrm{BB}$. One such gene that has been studied extensively is iNOS, which is expressed in airway epithelial cells and macrophages in asthma [52]. This increased iNOS expression is reflected by increased amounts of NO in exhaled air of asthmatic patients [53].

Whereas there are many similarities between the inflammatory responses in arthritis, asthma, inflammatory bowel disease and other inflammatory diseases, there are also important differences, and clearly factors other than $\mathrm{NF}-\kappa \mathrm{B}$ are involved [10]. These differences may relate to the secretion of specific cytokines, such as IL-5 in asthmatic inflammation which promotes an eosinophilic inflammation. The role of NF- $\kappa B$ should be seen as an amplifying and perpetuating mechanism that will exaggerate the disease-specific inflammatory process through the co-ordinated activation of multiple inflammatory genes. Thus, IL-5 alone results in relatively little accumulation of eosinophils within tissues, but this is enormously amplified by the local injection of the eosinophil specific chemokine, eotaxin, which is regulated via $\mathrm{NF}-\kappa \mathrm{B}$ [54].

\section{Activator protein-1}

AP-1 is a heterodimer of Fos and Jun oncoproteins, which is a member of the basic leucine zipper (bZIP) transcription family, characterized by a basic leucine-rich area that is involved with dimerization with other transcription factors (fig. 3). AP-1 was originally described by binding to the TPA (tetradecanoylphorbol-13-acetate) response element (TRE: 5'-TGAC/GTCA-3') and responsible for the transcriptional activation of various genes that were activated by phorbol esters (such as TPA, also known as PMA) via activation of protein kinase C (PKC) [55]. It is now apparent that AP-1 is a collection of related transcription factors belonging to the Fos (cFos, FosB, Fra1, Fra2) and Jun (c-Jun, JunB, JunD) families that dimerize in various combinations through their leucine zipper region. Fos/Jun heterodimers bind with the greatest affinity and are the predominant form of AP-1 in most cells, whereas Jun/Jun homodimers bind with a low affinity. AP-1 proteins may also form functionally distinct dimeric complexes with members of the related bZIP family of activating transcription factor (ATF)/CREB transcription factors.

AP-1 may be activated via $\mathrm{PKC}$ and by various cytokines, including TNF- $\alpha$ and IL-1 $\beta$ via several types of protein tyrosine kinase (PTK) and MAP kinase, which

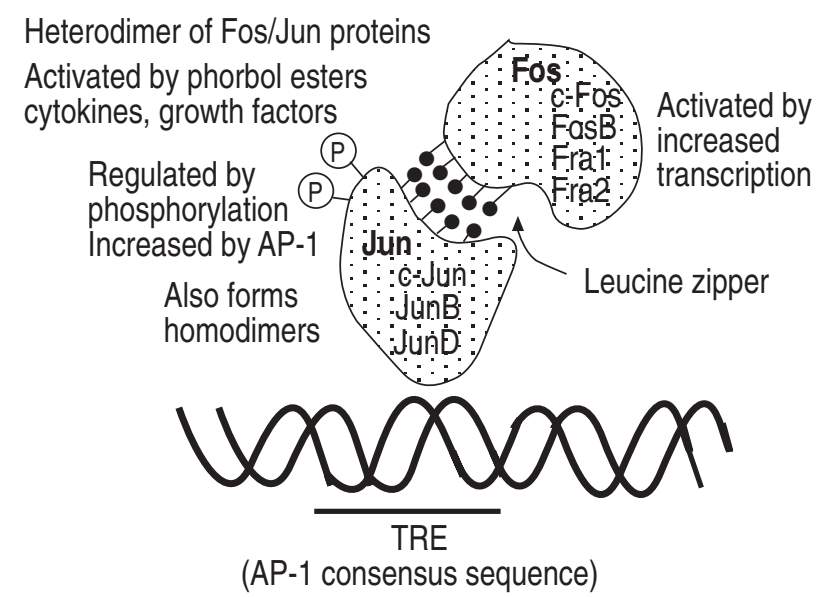

Fig. 3. - Activator protein (AP)-1 is a heterodimer of Fos and Jun proteins. 
themselves activate a cascade of intracellular kinases [56, 57]. Both TNF- $\alpha$ and IL- $1 \beta$ activate TNF-associated factors (TRAF), which subsequently activate MAP kinases [21]. Recent studies suggest that there may be interactions between the AP- 1 activating pathways and NF- $\kappa \mathrm{B}$ pathways, in that TRAF2 (activated by TNF- $\alpha$ ) and TRAF-6 (activated by IL-1 $\beta$ ) may both activate NIK and then IKK [21] (fig. 4).

We have demonstrated the activation of AP-1 in human lung after stimulation with PMA, TNF- $\alpha$ and IL- $1 \beta[50$, 58] and in peripheral blood mononuclear cells after activation with PMA [48]. Certain signals rapidly increase the transcription of the fos gene, resulting in increased synthesis of Fos protein. Other signals lead to activation of kinases that phosphorylate c-Jun, resulting in increased activation. Several specific JNKs are now recognized, and may play an important role in the regulation of cellular responsiveness to cytokine signals $[57,59,60]$. Conversely, a Jun phosphatase counteracts the activation of AP-1, and a deficiency of this enzyme might lead to amplification of chronic inflammation.

There is evidence for increased expression of c-Fos in epithelial cells in asthmatic airways [61], and many of the stimuli relevant to asthma that activate $\mathrm{NF}-\kappa \mathrm{B}$ will also activate AP-1. AP-1, like NF- $\kappa \mathrm{B}$, regulates many of the inflammatory and immune genes that are overexpressed in asthma. Indeed, many of these genes require the simultaneous activation of both the transcription factors that work together c-operatively.

The recognition that AP-1 may interact with other transcription factors indicates that cross-talk between different signal transduction pathways is possible [62]. The activated glucocorticoid receptor (GR) directly interacts with activated AP-1, and this may be an important action of steroids in inhibiting cytokine-mediated inflammatory res-ponses (see below). AP-1 also interacts with cell-specific transcription factors, such as NF-AT (see below).

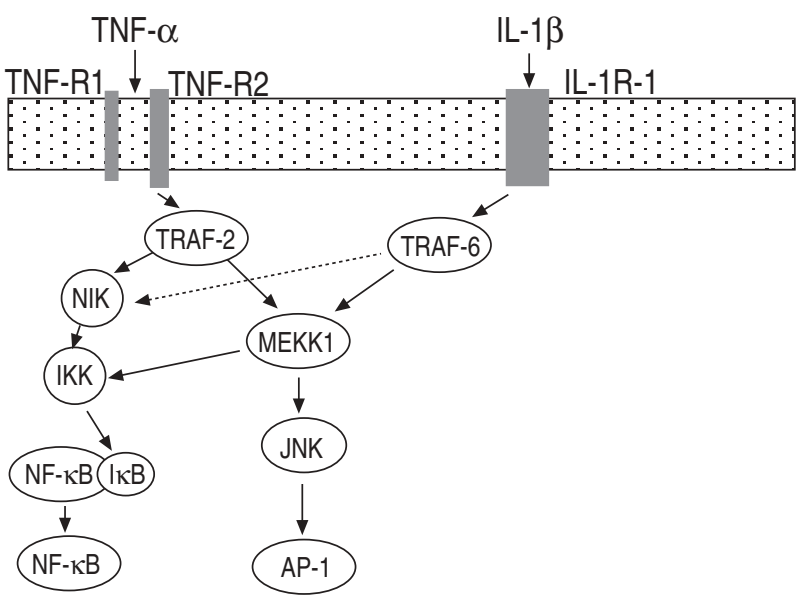

Fig. 4 - Interaction between activator protein (AP)-1 and nuclear factor (NF)- $\kappa$ B activating pathways. Tumour necrosis factor (TNF)- $\alpha$ binding to TNF-receptor-2 (TNF-R2) activates TNF-associated factor-2 (TRAF-2) that then activates NF- $\mathrm{KB}$ inducing kinase (NIK), which in turn leads to activation of NF- $\kappa \mathrm{B}$ via activation of the $\mathrm{I} \kappa \mathrm{B}$ kinase complex (IKK). TRAF-2 also activates a mitogen-activated protein (MAP) kinase enzyme, MEKK1, which leads to activation of Jun N-terminal kinase (JNK) and activation of AP-1. Similarly, interleukin (IL)-1 $\beta$ binds to the IL-1 receptor (IL-1R-1), leading to activation of TRAF-6, which also activates NIK and MEKK1, resulting in parallel activation of AP-1 and NF-B.

\section{CAAT/Enhancer binding proteins}

C/EBP are transcription factors important in IL-1, IL-6 and LPS-dependent signal transduction and bind to a consensus sequence ATTGCGCAAT, which includes the CAAT box. These transcription factors are members of the bZIP class of transcription factors and include $\mathrm{C} / \mathrm{EBP} \alpha, \mathrm{C} /$ $\mathrm{EBP} \beta, \mathrm{C} / \mathrm{EBP} \gamma$ and $\mathrm{C} / \mathrm{EBP} \delta$ [63]. These transcription factors are activated by pathways that involve $\mathrm{PKC}$ and regulate the expression of several inflammatory and immune genes. They often cooperate positively with other transcription factors, particularly other bZIP proteins, such as AP-1, ATF and CREB, but also with NF- $\kappa$ B. Thus, in the regulation of IL-8 gene expression, there is a marked enhancement of transcription when $\mathrm{C} / \mathrm{EBP} \beta$ is activated together with $\mathrm{NF}-\kappa \mathrm{B}$, whereas $\mathrm{C} / \mathrm{EBP} \beta$ activation alone has little effect [9]. Splice isoforms of these transcription factors, which appear to have blocking effects on transcription, have been identified.

The role of C/EBP in asthma has not yet been defined, but it is likely that activation of this transcription factor by inflammatory signals is an important amplifying mechanism for the expression of inflammatory genes, such as iNOS, COX-2 and certain chemokines, both of which have $\mathrm{C} / \mathrm{EBP} \beta$ recognition sequences in their promoter regions. Many of the effects of IL- 6 are mediated through activation of $\mathrm{C} / \mathrm{EBP} \beta$, and this cytokine is produced in increased amounts from macrophages of asthmatic patients [64] and is further enhanced by allergen exposure via lowaffinity immunoglobulin (Ig)E receptors (FceRII) [65]. Rhinovirus infection markedly increases the concentrations of IL-6 in induced sputum and levels remain elevated for several days [66].

\section{Janus kinase (JAK)-signal transducers and activators of transcription (STAT) family}

Several cytokines, including interferons (IFN) activate specific cytosolic tyrosine kinases known as Janus kinases (JAK) [67-69] (fig. 5). Members of the JAK family

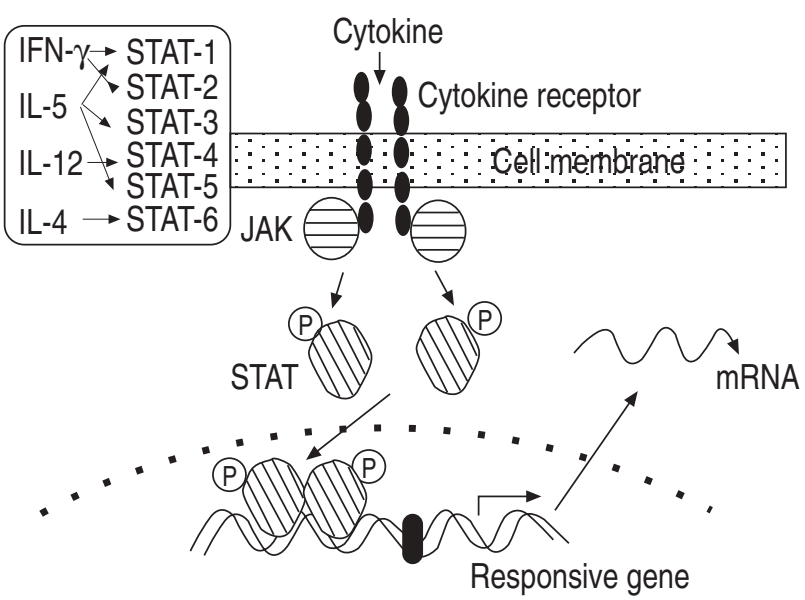

Fig. 5. - JAK-STAT pathways. Cytokine binding to its receptor results in the activation of Janus kinases (JAK) that phosphorylate intracellular domains of the receptor, resulting in phosphorylation of signal transduction-activated transcription factor (STATs). Activated STATs dimerize and translocate to the nucleus where they bind to a recognition element on certain genes. mRNA: messenger ribonucleic acid; IL: interleukin; IFN: interferon. 
include JAK1, JAK2, JAK3, tyrosine kinase (TyK)1 and TyK2 and may be differentially activated by different cytokines. Thus, IL-2 activates JAK1 and JAK3, IL-6 activates JAK1, JAK2 and JAK3, whereas IL-5 activates JAK2 only. JAKs are constitutively associated with the cytoplasmic domains of cytokine receptors and become activated upon ligand-induced receptor homo- or heterodimerization. JAKs then phosphorylate tyrosine residues on the cytoplasmic domains of cytokine receptors, which create docking domains for a family of transcription factors known as signal transducers and activators of transcription (STATs) [63]. Phosphorylation of the SH2 domain of STATs results in the formation of homo- or heterodimers that migrate to the nucleus, where they bind to response elements on promoter sequences to regulate the transcription of specific genes. An increasing number of STAT proteins have now been identified, and again, there is a specificity with particular cytokines. Thus, IFN- $\gamma$ activates STAT1 only, whereas IFN- $\alpha$ activates STAT1 and STAT2 to form a STAT1/STAT2 heterodimer, which bind to IFN- $\gamma$ activation sequences (GAS). STATs affect transcription by interacting with the co-activator molecules CBP and p300 [70, 71].

There is specificity in JAK-STAT pathways. Thus, IL-6 activates STAT3, whereas IL-4 activates STAT6 [72, 73]. STAT6 therefore provides a novel target for blocking the effects of IL-4 as a potential treatment for allergic asthma. STAT6 knockout mice have no response to IL-4, fail to produce IgE on allergen sensitization and do not develop Th2 cells in response to IL-4, indicating the critical role of STAT6 in allergic responses [74]. By contrast, IL-12 signals via activation of STAT4 [75]. STAT4 knockout mice have no response to IL-12 and have a propensity to develop T-helper (Th)2 lymphocytes [76]. IL-5 appears to activate several STATs, including STAT1, STAT3 and STAT5 $\alpha$ [77-79]. STAT, originally identified as a mediator of the growth effects of prolactin, also mediates the effects of GM-CSF [79].

Recently, inhibitors of STATs have been identified that are themselves regulated through JAK-STAT pathways and therefore provide a mechanism for switching of cytokine-triggered cellular signalling $[80,81]$.

\section{Cyclic AMP response element binding protein}

Increased concentrations of cyclic AMP (cAMP) also result in the activation or inhibition of gene transcription. CAMP activates protein kinase A (PKA), which phosphorylates a transcription factor $\mathrm{CREB}$ which binds to a cAMP response element (CRE) in the promoter region of certain genes [82] (fig. 6). CREB is a member of large family of CRE binding proteins, including members of the ATF family. CREB itself binds to CBP that acts as a co-activator molecule that binds to the TATA box and initiates transcription [83]. CREB may be counteracted by another transcription factor called CRE modulator (CREM) that may block the effects of CREB on CRE (although some splice variants appear to increase CRE binding). CREB appears to be important in the regulation of $\beta_{2}$-adrenoceptor expression [84]. It is activated by relatively high concentrations of $\beta_{2}$-agonists in lung [85] and may play a role in the downregulation of $\beta_{2}$-receptors after chronic exposure

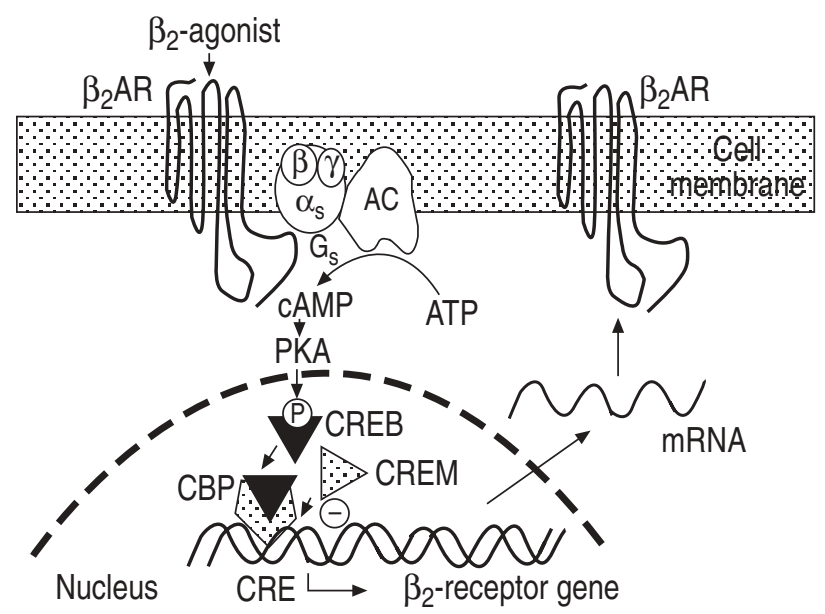

Fig. 6. - Effect of $\beta$-agonists on gene transcription. An increase in cyclic AMP (cAMP) activates protein kinase A (PKA), resulting in phosphorylation of cAMP response element binding protein (CREB) within the nucleus, which binds to a cAMP response element (CRE) in the upstream promoter region of a responsive gene (e.g., the $\beta_{2}$-receptor gene itself), resulting in increased transcription. Binding of CREB to CRE is facilitated by CREB binding protein (CBP) and may be blocked by another transcription factor, CRE modulator (CREM). mRNA: messenger ribonucleic acid; $\beta_{2} \mathrm{AR}$ : $\beta_{2}$-adrenoreceptor; AMP and ATP: adenosine mono- and triphosphate; $\mathrm{AC}$ : adenylate cyclase.

to $\beta_{2}$-agonists $[86,87]$. CREB also regulates the expression of several immune and inflammatory genes, including GM-CSF and IL-5.

CREB interacts directly with other transcription factors, allowing cross-talk between different signalling pathways. Thus, CREB has a negative effect on AP-1 [88] and glucocorticoid receptor (GR) [89]. High concentrations of $\beta$ agonists inhibit the binding of GR to DNA $[85,90]$. This may interfere with the anti-inflammatory effects of steroids and may account for the deleterious effects of high dose inhaled $\beta$-agonists in patients with asthma [91].

\section{CREB binding protein (CBP)}

Recent evidence suggests that several transcription factors interact with large co-activator molecules, such as CBP and the related $\mathrm{p} 300$, which bind to the basal transcription factor apparatus [92]. Several transcription factors have now been shown to bind directly to CBP, including AP-1, NF- $\kappa \mathrm{B}$ and STATs [71, 93-95]. Since binding sites on this molecule may be limited, this may result in competition between transcription factors for the limited binding sites available, so that there is an indirect, rather than a direct, protein-protein interaction (fig. 7). CBP also interacts with nuclear hormone receptors, such as GR and retinoic acid. These nuclear hormone receptors may interact with CBP and the basal transcriptional apparatus through binding to other nuclear co-activator proteins, including steroid rec-eptor co-activator-1 (SRC-1) [96, 97], transcription factor intermediary factor-2 (TIF2) or glucocorticoid receptor interacting protein-1 (for the glucocorticoid receptor) [98]. A newly described nuclear protein called p300/CBP co-integrator-associated protein (p/CIP) appears to be partic-ularly important in the binding of several nuclear receptors to CBP/p300 [99]. These nuclear activator proteins associate with nuclear receptors via a common sequence LXXLL (where $\mathrm{L}$ is lysine and $\mathrm{X}$ is any amino acid) [100]. 


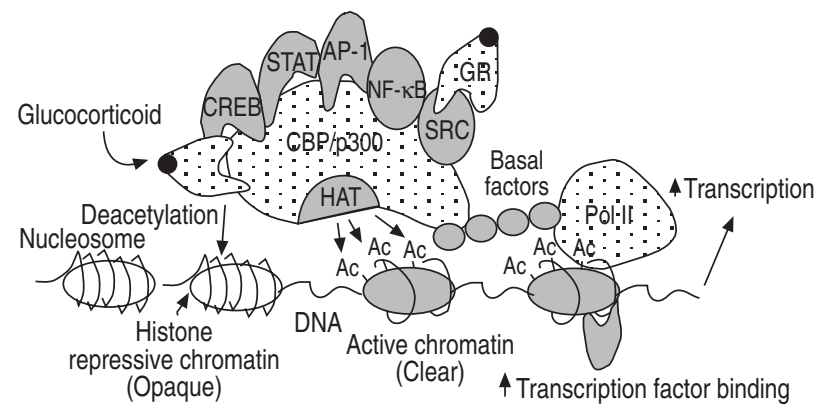

Fig. 7. - Co-activator molecules. Transcription factors, such as signaltransduction-activated transcription factors (STAT)s, activator protein (AP)-1 and nuclear factor (NF)- $\mathrm{KB}$ bind to co-activator molecules, such as CREB binding protein (CBP) or p300, which have an intrinsic histone acetyltransferase (HAT) activity, resulting in acetylation (-Ac) of histone proteins around which deoxyribonucleic acid (DNA) is wound in the chromosome. This leads to unwinding of DNA and allows increased binding of transcription factors resulting in creased gene transcription. Glucocorticoid receptors (GR) after activation by corticosteroids bind to a steroid receptor co-activator (SRC) that is bound to CBP. This result in deacetylation of histone, with increased coiling of DNA around histone, thus preventing transcription factor binding leading to gene repression. CREB: cyclic adenosine monophosphate element binding protein. Pol II: DNA polymerase II.

DNA is wound around histone proteins to form nucleosomes and the chromatin fibre in chromosomes. It has long been recognized at a microscopic level that chromatin may become dense or opaque due to the winding or unwinding of DNA around the histone core. CBP and p300 have histone acetylation activity that is activated by the binding of transcription factors, such as AP-1 and NF- $\kappa B$ [101]. Acetylation of histone residues results in unwinding of DNA coiled around the histone core, thus opening up the chromatin structure, which allows transcription factors to bind more readily, thereby increasing transcription (fig. 7). Repression of genes reverses this process by histone deacetylation [102]. The process of deacetylation involves the binding of hormone or vitamin receptors to co-repressor molecules, such as nuclear receptor co-repressor (N-CoR), which forms a complex with another repressor molecule Sin3 and a histone deacetylase $[103,104]$. Deacetylation of histone, increases the winding of DNA around histone residues, resulting in dense chromatin structure and reduced access of transcription factors to their binding sites, thereby leading to repressed transcription of inflammatory genes.

\section{Glucocorticoid receptors (GRs)}

GRs are members of the nuclear receptor superfamily that includes other steroids (oestrogen, progesterone), receptors for vitamins (vitamins A and D) and thyroid hormone. GRs are transcription factors that regulate the transcription of several steroid-responsive target genes. GRs are expressed in most types of cell, and in human lung there is a high level of expression in airway epithelium and the endothelium of bronchial vessels [105]. The inactive GR is bound to a protein complex that includes two molecules of a $90 \mathrm{kDa}$ heat shock protein (hsp90) and an immunophilin, which act as molecular chaperones, protecting the nuclear localization site. Glucocorticoids bind to GRs in the cytoplasm, resulting in the dissociation of these molecules and rapid nuclear localization and DNA binding. GRs form homodimers to interact with glucocorticoid response elements (GRE: GGTACAnnnTGTTCT), resulting in increased gene transcription [106]. Recently, it has become apparent that steroid receptors bound to DNA may interact with CBP to enhance transcription and the adenovirus protein $\mathrm{E} 1 \mathrm{~A}$, which inactivates $\mathrm{CBP}$, interferes with the action of steroids [96]. Steroids interact with CBP through binding of their ligand-activated GRs to $\mathrm{p} / \mathrm{CIP}$ and other nuclear proteins [99].

Relatively few genes have GREs. One well-studied example is the human $\beta_{2}$-adrenoceptor gene that has at least three GREs [84]. Corticosteroids increase the transcription of $\beta_{2}$-receptors in animal and human lung, and this may prevent tolerance to the effects of $\beta_{2}$-agonists by compensating for their downregulation [87, 107]. Corticosteroids also increase the transcription of several anti-inflammatory proteins, including lipocortin-1, serum leukoprotease inhibitor, CC-10 and IL-1 receptor antagonist and these effects are presumably also mediated via GREs in the promoter regions of these genes [108]. Corticosteroids have also been reported to increase the expression of I $\mathrm{I} B-\alpha$ in lymphocytes and thus to inhibit NF- $\mathrm{BB}[45,109]$, but this has not been seen in other cell types [110-112]. The IKB- $\alpha$ gene does not appear to have any GRE consensus sequence so the effect of corticosteroids is probably mediated via other transcription factors.

\section{Interaction with other transcription factors}

The major anti-inflammatory effects of corticosteroids are via repression of inflammatory and immune genes, and it was thought that this was likely to be mediated through negative GREs (nGREs), resulting in gene repression. However, none of the inflammatory and immune genes that are switched off by steroids in asthma appears to have nGREs in their promoter sequences, suggesting that there must be some less direct inhibitory mechanism. The inhibitory effect of corticosteroids appears to be due largely to a protein-protein interaction between activated GR and transcription factors, such as AP- $1, N F-\kappa B$ and $\mathrm{C} /$ EBP, that mediate the expression of these inflammatory genes [113] (fig. 8). Direct protein-protein interactions have been demonstrated between GR and AP-1 [6, 62], between the p65 component of NF- $\mathrm{BB}[48,114,115]$ and some STAT proteins, such as STATs [116], suggesting that corticosteroids block the binding or activation of these transcription factors and thus suppress activated inflammatory genes.

There has recently been increasing evidence that corticosteroids may have effects on the chromatin structure of DNA. The repressive action of steroids may be because of competition between GR and the binding sites on CBP for other transcription factors, including AP-1, NF- $\kappa \mathrm{B}$ and STATs [71, 93-95]. Activated GR may bind to several transcription co-repressor molecules that associate with proteins that have histone deacetylase activity, resulting in deacetylation of histone, increased winding of DNA round histone residues and thus reduced access of transcription factors to their binding sites and therefore repression of inflammatory genes [102] (fig. 7).

A good example is the inhibitory effect of steroids on iNOS expression. iNOS is largely regulated via $\mathrm{NF}-\kappa \mathrm{B}$ [36] and the inhibitory effect of glucocorticoids on the 


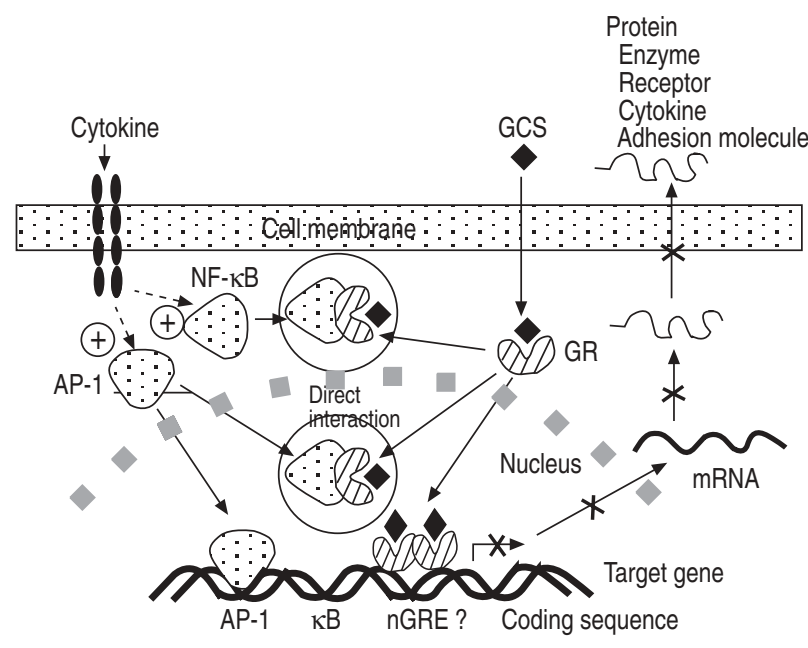

Fig. 8. - Mechanism of gene repression by corticosteroids. There is little evidence that glucocorticoid receptors (GR) interact with negative glucocorticoids response elements (nGRE). Direct interaction between the transcription factors activator protein (AP)-1 and nuclear factor $(\mathrm{NF})-\kappa \mathrm{B}$ and the glucocorticoid receptor may result in mutual repression. In this way, steroids may counteract the chronic inflammatory effects of cytokines and other stimuli that activate these transcription factors. mRNA: messenger ribonucleic acid; GCS: glucocorticosteroid.

induction of iNOS appears to be due to a direct interaction of GR and the p65 component of NF- $\kappa B$ [117]. This results in reduced iNOS expression in asthmatic airways [118] and a reduction in exhaled nitric oxide [119]. Similarly, the eosinophil chemotactic cytokine RANTES, which is upregulated in asthmatic airways, is inhibited by corticosteroids [120-122]. This is likely to be due to an interaction of GR with NF- $\mathrm{KB}$ and AP-1, which are important determinants of RANTES expression [33].

The effect of steroid receptor activation is to interfere with the activation of CBP, which regulates acetylation of the histone around which DNA is coiled. The effect of steroids is to result in deacetylation of histone residues and thus to tighter coiling of DNA, thus excluding transcription factors such, as NF- $\kappa \mathrm{B}$ and AP-1, from binding to DNA [94].

\section{Steroid-resistant asthma}

A small proportion of asthmatic patients are steroid-resistant and fail to respond to even high doses of oral steroids [123-125]. This defect is also seen in mononuclear cells and T-lymphocytes isolated from these patients. A reduction in the number or affinity of GRs cannot account for the profound loss of steroid responsiveness, but we have found a marked impairment of GRE binding after exposure of mononuclear cells to steroids in vitro [126]. This is associated with a marked reduction in the number of activated GRs available for binding. In the same patients there is a reduced inhibitory effect of corticosteroids on AP-1 activation, but not on NF- $\kappa \mathrm{B}$ or CREB activation [127]. Furthermore, there is an increase in the baseline activity of AP-1 and activation of AP-1 with phorbol esters showing a greatly exaggerated expression of c-Fos due to increased gene transcription [128]. This appears to be due to excessive activation of JNK at baseline and in response to TNF- $\alpha$ [129]. The increased activation of AP-1 may result in sequestration of GRs so that no recep- tors are available for inhibiting NF- $\kappa \mathrm{B}, \mathrm{C} / \mathrm{EBP}$ etc., thus resulting in steroid resistance. This resistance will be seen at the site of inflammation where cytokines are produced, i.e. in the airways of asthmatic patients, but not at noninflamed sites. This may explain why patients with steroid-resistant asthma are not resistant to the endocrine and metabolic effects of steroids, and thus develop steroid side effects 1130]. Whether this abnormality is inherited is not yet certain, although there is often a positive family history of asthma in patients with steroid-resistant asthma, indicating that genetic factors may be important.

\section{Nuclear factor of activated T-cells (NF-AT)}

NF-AT is a good example of a cell-specific transcription factor, as it is predominantly found in T-lymphocytes, although it is also found in other cells such as mast cells. NF-AT is of key importance in the regulation of the expression of IL-2 and probably other T-cell derived cytokines, such as IL-4 and IL-5. Activation of T-cells results in activation of the phosphatase calcineurin, which activates a preformed cytoplasmic NF-AT (NF-ATp) (fig. 9). Calcineurin binds tightly to NF-ATp and is transported into the nucleus where it continues to dephosphorylate NF-AT counteracting an NF-AT kinase [131]. At least three other forms of NF-AT have now been identified (NF-Atc, NF-AT3 and NF-AT4) and are differentially expressed in different tissues; all have a Rel-like domain [132]. AP-1 forms a transcriptional complex with NF-AT (the nuclear NF-AT previously identified) by interacting with the Rel domain to increase IL-2 gene expression [133-135]. This may be inhibited by cyclosporin A and tacrolimus (FK 506) which inhibit calcineurin, or by steroids which inhibit AP-1 directly. This predicts that there is a synergistic interaction between cyclosporin A and steroid in inhibiting cytokine gene expression in T-cells, and this has recently been confirmed in studies of lymphocyte proliferation and transcription factor suppression [136].

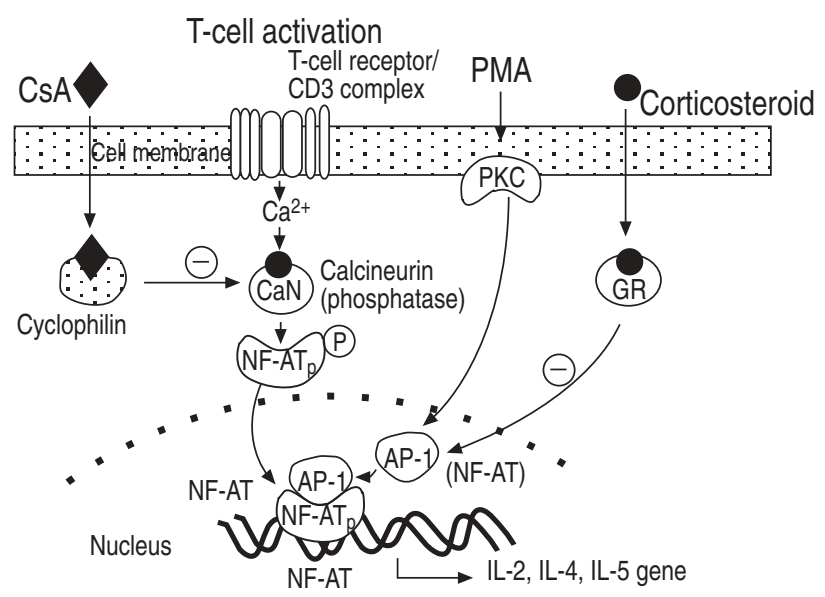

Fig. 9. - Nuclear factor of activated T-cells (NF-AT) regulates expression interleukin (IL)-2, IL-4 and IL-5. It is made up of a cytoplasmic component (NF-ATp) and activator protein (AP)-1. Cyclosporin (CsA) inhibits NF-AT by inhibiting the activity of calcineurin $(\mathrm{CaN})$, which is needed for activation of NF-AT, whereas steroids inhibit by blocking the AP-1 component. This predicts a synergy between these two drugs. GR: glucocorticoid receptor; PMA: phorbol myristate acetate; PKC: protein kinase $\mathrm{C}$ 
NF-ATp is important for the regulation of IL-4 and IL-5 genes [137]. NF-AT cooperates with AP-1 in the expression of IL-4 in mice [138], and knock-out of the NF-ATp gene results in defective IL-4 production [139]. Recently, an additional transcription factor called NF-AT interacting protein (NIP-45) has been described that appears to be involved in the activation of NF-AT and the proto-oncogene c-Maf to activate IL-4 transcription [140]. NF-AT is also implicated in the transcription of IL-5 in T-lymphocytes and mast cells, acting in concert with another transcription factor GATA [141, 142]. Corticosteroids potently inhibit IL-5 gene transcription, and this may be via inhibitory effects on AP-1, that interacts with NF-ATp [143].

\section{Therapeutic implications}

The increased understanding of transcription factors has given new insights into the pathophysiology of asthma, but has also opened an opportunity for the development of new antiasthma treatments. Several new therapies based on interactions with specific transcription factors or their activation pathways are now in development for the treatment of chronic inflammatory diseases and several drugs already in clinical use (corticosteroids, retinoic acid, cyclosporin A) work via transcription factors [144]. One concern about this approach is the specificity of such drugs, but it is clear that transcription factors have selective effects on the expression of certain genes and this may make it possible to be more selective. In addition, there are cellspecific transcription factors that may be targeted for inhibition, which could provide a selectivity of drug action. One such example is NF-AT, blocked by cyclosporin A and tacrolimus, which has a restricted cellular distribution. In asthma, it may be possible to target drugs to the airways by inhalation, as is currently done for inhaled corticosteroids to avoid any systemic effects.

\section{New steroids}

The recognition that most of the anti-inflammatory effects of steroids are mediated by repression of transcription factors (transrepression), whereas the endocrine and metabolic effects of steroids are likely to be mediated via GRE binding (transactivation) has led to a search for novel corticosteroids that selectively transrepress, thus reducing the risk of systemic side effects. Since corticosteroids bind to the same GR, this seems at first to be an unlikely possibility, but whereas GRE binding involved a GR homodimer, interaction with transcription factors AP-1 and $\mathrm{NF}-\kappa \mathrm{B}$ involves only a single GR. A separation of transactivation and transrepression has been demonstrated using reporter gene constructs in transfected cells using selective mutations of GR [145]. Furthermore, some steroids, such as the antagonist RU486, have a greater transrepression than transactivation effect. Indeed, the topical steroids used in asthma therapy today, such as fluticasone propionate and budesonide, appear to have a more potent transrepression than transactivation effects, which may account for their selection as potent anti-inflammatory agents [146]. Recently, a novel class of steroids has been des-cribed in which there is potent transrepression with relatively little transactivation. These "dissociated" steroids, including
RU24858 and RU40066 have anti-inflammatory effects in vivo [147]. This suggests that the development of steroids with a greater margin of safety is possible and may predict the development of oral steroids to use in asthma.

\section{$N F-\kappa B$ inhibitors}

Since NF- $\kappa$ B may play a pivotal role in asthma, this has suggested that specific NF- $\mathrm{\kappa B}$ inhibitors might be beneficial in asthma therapy [148]. Antioxidants which can block activation of NF- $\mathrm{KB}$ in response to a wide variety of stimuli and drugs, such as pyrrolidine dithiocarbamate, have proved useful for in vitro studies, but are too toxic for in vivo development [28]. Spin-trap antioxidants may be more effective since they work at an intracellular level [149]. However, antioxidants do not block all of the effects of NF- $\mathrm{BB}$, and this may require the development of novel drugs.

Some naturally occurring NF- $\kappa \mathrm{B}$ inhibitors have already been identified. Thus gliotoxin, derived from Aspergillus, is a potent NF- $\kappa \mathrm{B}$ inhibitor that appears to be relatively specific [150]. The anti-inflammatory cytokine IL-10 also has an inhibitory effect on NF- $\kappa \mathrm{B}$, via an effect on I $\kappa \mathrm{B}-\alpha$ [151], and is another therapeutic possibility particularly as there appears to be a deficit in IL-10 secretion in airway macrophages from asthmatic patients that is correlated with increases secretion of pro-inflammatory cytokines and chemokines [152].

Novel approaches to inhibition of NF- $\kappa \mathrm{B}$ would be to develop specific inhibitors of I $\mathrm{B}$ kinases involved in the initial activation of NF- $\kappa \mathrm{B}$, to block the signal transduction pathways leading to activation of $\mathrm{I} \kappa \mathrm{B}$ kinases. Now that IкB kinases have been identified, it may be possible to screen and design specific inhibitors. It may also be possible to inhibit the activity of the enzymes responsible for its degradation of the IKB complex, although the proteasome has many other important functions, and its inhibition is likely to produce severe side effects. Recently, it has been possible to block NF- $\kappa \mathrm{B}$ function by targeting of a specific enzyme (ubiquitin ligase) involved in conjugation of ubiquitin [153]. It may be more difficult to develop drugs to directly inhibit the components of NF- $\kappa \mathrm{B}$ itself, but antisense oligonucleotides have been shown to be effective inhibitors in vitro, and stable cell permeable phosphorothioate oligonucleotides are a therapeutic possibility in the future. Recently, adenovirus- mediated gene transfer of I $\mathrm{KB}-\alpha$ has been reported to inhibit endothelial cell activation [154].

However, it may be unwise to block NF- $\kappa \mathrm{B}$ for prolonged periods, as it plays such a critical role in immune and host defence responses. Targeted disruption ("knockout") of p65 is lethal because of developmental abnormalities [14], whereas a lack of p50 results in immune deficiencies and increased susceptibility to infection [15]. Topical application of NF- $\mathrm{BB}$ inhibitors by inhalation may prove to be safe, however.

\section{Drug interactions}

One of the most important implications of research on transcription factors is that multiple and complex interactions between these proteins are possible and this leads to cross-talk between different signal transduction pathways. This might be exploited therapeutically by the combina- 
tion of drugs that act on different transcript factors or pathways that may work together co-operatively. For example, NF-AT has a cytoplasmic component (NF-ATp) which is blocked by cyclosporin and tacrolimus, and a nuclear component AP-1, which is blocked by corticosteroids (fig. 9). Combining steroids and cyclosporin may therefore have a synergistic inhibitory effect on the expression on genes such as IL-2, IL-4 and IL-5. This has indeed been demonstrated for IL-2 in human T-cells, where a combination of both drugs has a much greater suppressive effect than either drug alone [136]. This suggests that a dose of cyclosporin A that is too low to produce nephrotoxic side effects, may be combined with an inhaled steroid, so that this synergistic interaction is confined to the airways.

Another interaction that may be exploited therapeutically is that between retinoic acid and steroids. Retinoic acid (vitamin A) binds to retinoic acid receptors that, like GR, bind to CBP. There appears to be a synergistic interaction between steroids and retinoic acid in repression of transcription factors, such as NF- $\mathrm{KB}$ and $\mathrm{AP}-1$, presumably because of competition for binding sites on CBP. A synergistic interaction between retinoic acid and steroids has been demonstrated in the suppression of GM-CSF release from cultured epithelial cells, suggesting that retinoic acid may potentiate the anti-inflammatory effects of steroids [155]. Novel retinoic acid derivatives activate a subtype of retinoic acid receptor (RXR) that interacts with these transcription factors, and therefore, it may be possible to develop more selective retinoids for this purpose [156].

\section{References}

1. Hunter T, Karin.M. The regulation of transcription by phosphorylation. Cell 1992; 70: 375-387.

2. Karin M, Smeal T. Control of transcription factors by signal transduction pathways: the beginning of the end. Trends Biochem Sci 1993; 17: 418-422.

3. Adcock IM, Barnes PJ. Transcription factors. In: Crystal RG, West JB, Weibel WR, Barnes PJ, eds. The Lung: Scientific Foundations. Philadelphia, Lippincott-Raven, 1996; pp. 255-276.

4. Latchman DS. Transcription-factor mutations and disease. N Engl J Med 1996; 334: 28-33.

5. Papavassilou AG. Transcription factors. $N$ Engl J Med 1995; 332: 45-47.

6. Pfahl M. Nuclear receptor/AP-1 interaction. Endocr Rev 1993; 14: 651-658.

7. Tjian R, Maniatis T. Transcriptional activation: a complex puzzle with few easy pieces. Cell 1994; 77: 5-8.

8. Lalli E, Sassone-Corsi P. Signal transduction and gene regulation: the nuclear response to cAMP. J Biol Chem 1994; 269: 17359-17362.

9. Stein B, Baldwin AS. Distinct mechanisms for the regulation of the interleukin-8 gene involve synergism and cooperativity between CIEBP and NF- $\mathrm{KB}$. Mol Cell Biol 1993; 13: 7191-7198.

10. Barnes PJ, Karin M. Nuclear factor- $\mathrm{kB}$ : a pivotal transcription factor in chronic inflammatory diseases. $N$ Engl J Med 1997; 336: 1066-1071.

11. Sen R, Baltimore D. Multiple nuclear factors interact with the immunoglobulin enhancer sequences. Cell 1986; 46: 705-716.

12. Siebenlist U, Franzuso G, Brown R. Structure, regulation and function of NF-кB. Annu Rev Cell Biol 1994; 10: 405-455.

13. Baeuerle PA, Henkel T. Function and activation of NF- $\kappa B$ in the immune system. Annu Rev Immunol 1994; 12: 141-179.

14. Beg AA, Sha WC, Bronson RT, Ghosh S, Baltimore D. Embroyonic lethality and liver degeneration in mice lacking the RelA component of NF-אB. Nature 1995; 376: 167-170.

15. Sha WC, Liou HC, Tuomanen EI, Baltimore D. Targeted disruption of the p50 subunit of NF- $\mathrm{KB}$ leads to multifocal defects in immune responses. Cell 1995; 80: 321330.

16. Baldwin AS. The NF- $\kappa B$ and IкB proteins: new discoveries and insights. Annu Rev Immunol 1996; 14: 649-681.

17. Baeuerle PA, Baltimore D. NF-אB: ten years on. Cell 1996; 87: 13-20.

18. DiDonato J, Mercurio F, Rosette C, et al. Mapping of the inducible IKB phosphorylation sites that signal its ubiquitination and degradation. Mol cen Biol 1996; 16: 12951304.

19. Chen ZJ, Parent L, Maniatis T. Site-specific phosphorylation of IKB $\alpha$ by a novel ubiquitination dependent protein kinase activity. Cell 1996; 84: 853-862.

20. Zandi E, Rothwarf DM, Delhase M, Hayakawa M, Karin M. The IKB kinase complex (IKK) contains two kinase subunits, IKK $\alpha$ and IKK $\beta$, necessary for IKB phosphorylation and NF-KB activation. Cell 1997; 91: 243-252.

21. Eder J. Tumour necrosis factor $\alpha$ and interleukin 1 signalling: do MAPKK kineses connect it all? Trends Pharmacol Sci 1997; 18: 319-322.

22. Malinin NL, Boldin MP, Kovalenko AV, Wallach D. MAP3K-related kinase is involved in NF- $\mathrm{KB}$ induction by TNF, CD95 and IL-1. Nature 1997; 385: 540-544.

23. Lee FS, Hagler J, Chen ZJ, Maniatis T. Activation of the I $\mathrm{B} \alpha$ kinase complex by MEKK1, a kinase of the JNK pathway. Cell 1997; 88: 213-222.

24. Arenzana-Seisdedos F, Thomson J, Rodriguez MS, Bachelerie F, Thomas D, Hay RT. Inducible nuclear expression of newly synthesized I $\mathrm{K} \mathrm{B} \alpha$ negatively regulates DNA binding and transcriptional activity of NF- $\mathrm{KB}$. Mol Cell Biol 1995; 15: 2689-2696.

25. Adcock IM, Barnes PJ. Tumour necrosis factor a causes retention of activated glucocorticoid receptor within the cytoplasm of A549 cells. Biochem Biophys Res Commun 1996; 225: 1127-1132.

26. Klement JF, Rice NR, Car BD, et al. I $\mathrm{BB} \alpha$ deficiency results in a sustained NF- $\kappa \mathrm{B}$ response and severe widespread dermatitis in mice. Mol Cell Biol 1996; 16: 23412349.

27. Thompson JE, Phillips RJ, Erdjument-Bromage H, Tempst $\mathrm{P}$, Ghosh S. IкB- $\beta$ regulates the persistent response in a biphasic activation of NF-кB. Cell 1995; 80: 573-582.

28. Schreck R, Rieber P, Baeuerle PA. Reactive oxygen intermediates as apparently widely used messengers in the activation of the NF- $\mathrm{KB}$ transcription factor and HIV-1. EMBO J 1991; 10: 2247-2258.

29. Zhu Z, Tang W, Ray A, et al. Rhinovirus stimulation of interleukin-6 in vivo and in vitro. Evidence for nuclear factor $\mathrm{\kappa B}$-dependent transcription activation. J Clin Invest 1996; 97: 421-430.

30. Schreck R, Meier B, Männel DN, Dröge W, Baeuerle PA. Dithiocarbanates as potent inhibitors of nuclear factor $\mathrm{kB}$ activation in intact cells. J Exp Med 1991; 175: 1181.

31. Stein B, Baldwin AS, Ballard DW, Greene WC, Angel P, Herrlich P. Cross-coupling of the NF- $\kappa B$ p65 and Fos/Jun transcription factors produces potentiated biological 
function. $E M B O J$ 1993; 12: 3879-3891.

32. Mukaido N, Morita M, Ishikawa Y, Rice N, Okamoto S, Kasahara T, Matsushima K. Novel mechanisms of glucocorticoid-mediated gene repression: NFKB is target for glucocorticoid-mediated IL-8 gene expression. J Biol Chem 1994; 269: 13289-13295.

33. Nelson PJ, Kim HT, Manning WC, Goralski TJ, Krensky AM. Genomic organisation and transcriptional regulation of the RANTES chemokine gene. J Immunol 1993; 151: 2601-2612.

34. Ueda A, Okoda K, Shira A, et al. NF- $\kappa \mathrm{B}$ and Sp1 regulate transcription of the human monocyte chemoattractant protein-1 gene. J Immunol 1994; 153: 2052-2063.

35. Lilly CM, Nakamura H, Kesselman $\mathrm{H}$, et al. Expression of eotaxin by human lung epithelial cells: induction by cytokines and inhibition by glucocorticoids. J Clin Invest 1997; 99: 1767-1773.

36. Xie Q, Kashiwarbara Y, Nathan C. Role of transcription factor NF- $\mathrm{BB} / \mathrm{Rel}$ in induction of nitric oxide synthase. $J$ Biol Chem 1994; 269: 4705-4708.

37. Yamamoto K, Arakawa T, Ueda N, Yamamoto S. Transcriptional roles of nuclear factor $\mathrm{KB}$ and nuclear factorinterleukin 6 in the tumor necrosis- $\alpha$-dependent induction of cyclooxygenase-2 in MC3T3-E1 cells. J Biol Chem 1995; 270: 31315-31320.

38. Newton R, Kuitert LM, Bergmann M, Adcock IM, Bames PJ. Evidence for involvement of NF- $\kappa B$ in the transcriptional control of COX-2 gene expression by IL-1ß. Biochem Biophys Res Commun 1997; 237: 28-32.

39. Iademarco MF, McQuillan JJ, Rosen GD, Dean DC. Characterization of the promoter for vascular adhesion molecule-1 (VCAM-1). J Biol Chem 1995; 267: $16323-$ 16329.

40. Van De Stolpe A, Caldenhoven E, Stade BG, et al. 12-O-tetradecanoyl phorbol-13-acetate and tumor necrosis factor alpha-mediated induction of intercellular adhesion molecule-1 is inhibited by dexamethasone. Functional analysis of the human intercellular adhesion molecule-1 promoter. J Biol Chem 1994; 269: 6185-6192.

41. Liu ZG, Hsu H, Goeddel DV, Karin M. Dissection of TNF receptor 1 effector functions: JNK activation is not linked to apoptosis while NF- $\mathrm{BB}$ activation prevents cell death. Cell 1996; 87: 565-576.

42. Beg AA, Baltimore D. An essential role for NF- $\kappa \mathrm{B}$ in preventing TNF- $\alpha$-induced cell death. Science 1996; 274 : 782-784.

43. Liu SF, Haddad E, Adcock IM, et al. Inducible nitric oxide synthase after sensitization and allergen challenge of Brown Norway rat lung. Br J Pharmacol 1997; 121: 1241-1246.

44. Haddad E-B, Liu SF, Salmon M, Robichaud A, Barnes PJ, Chung KF. Expression of inducible nitric oxide synthase mRNA in Brown-Norway rats exposed to ozone: effect of dexamethasone. Eur J Pharmacol 1995; 293: 287-290.

45. Auphan N, DiDonato JA, Rosette C, Helmberg A, Karin M. Immunosuppression by glucocorticoids: inhibition of $\mathrm{NF}-\kappa \mathrm{B}$ activity through induction of IкB synthesis. Science 1995; 270: 286-290.

46. Adcock IM, Brown CR, Kwon OJ, Barnes PJ. Oxidative stress induces NF- $\kappa$ B DNA binding and inducible NOS mRNA in human epithelial cells. Biochem Biophys Res Commun 1994; 199: 1518-1524.

47. Haddad E-B, Salmon M, Koto H, Barnes PJ, Adcock I, Chung KF. Ozone induction of cytokine-induced neutrophil chemoattractant and nuclear factor- $\mathrm{\kappa B}$ in rat lung: inhibition by corticosteroids. FEBS Lett 1996; 379: 265-
268.

48. Adcock IM, Brown CR, Gelder CM, Shirasaki H, Peters MJ, Barnes PJ. The effects of glucocorticoids on transcription factor activation in human peripheral blood monoclucear cells. Am J Physiol 1995; 37: C331-C338.

49. Jany B, Betz R, Schreck R. Activation of the transcription factor NF- $\mathrm{KB}$ in human tracheobronchial epithelial cells by inflammatory stimuli. Eur Respir J 1995; 8: 387391.

50. Adcock IM, Brown CR, Shirasaki H, Barnes PJ. Effects of dexamethasone on cytokine and phorbol ester stimulated c-Fos and c-dun DNA binding and gene expression in human lung. Eur Respir J 1994; 7: 2117-2123.

51. Hart L, Krishnan VJ, Adcock IM, Barnes PJ, Chung KF. Activation and localization of transcription factor nuclear factor- $\mathrm{\kappa B}$ in asthma. Am J Respir Crit Care Med 1997.

52. Hamid Q, Springall DR, Riveros-Moreno V, et al. Induction of nitric oxide synthase in asthma. Lancet 1993; 342: 1510-1513.

53. Kharitonov SA, Yates D, Robbins RA, Logan-Sinclair R, Shinebourne E, Barnes PJ. Increased nitric oxide in exhaled air of asthmatic patients. Lancet 1994; 343: 133-135.

54. Collins PD, Marleau S, Griffiths-Johnson DA, Jose PJ, Williams TJ. Cooperation between interleukin-5 and the chemokine eotaxin to induce eosinophil accumulation in vivo. J Exp Med 1995; 182: 1169-1174.

55. Hai T, Curran T. Cross-family dimerization of transcription factors Fos/Jun and ATF/CREB alters DNA binding specificity. Proc Natl Acad Sci USA 1991; 88: 1-5.

56. Karin M. The regulation of AP-1 activity by mitogen-activated protein kineses. J Biol Chem 1995; 270: 16483-16486.

57. Karin M, Liu Zg, Zandi E. AP-1 function and regulation. Curr Opin Cell Biol 1997; 9: 240-246.

58. Adcock IM, Shirasaki H, Gelder CM, Peters MJ, Brown CR, Barnes PJ. The effects of glucocorticoids on phorbol ester and cytokine stimulated transcription factor activation in human lung. Life Sci 1994; 55: 1147-1153.

59. Kyriakis JM, Bangrjee P, Nikolakaki E, et al. The stress-activated protein kinase subfamily of c-Jun kineses. Nature 1994; 369: 156-160.

60. Westwick JK, Weitzel C, Minden A, Karin M, Brenner DA. Tumor necrosis factor alpha stimulates AP-1 activity through prolonged activation of the c-Jun kinase. $J$ Biol Chem 1994; 269: 26396-26401.

61. Demoly P, Basset-Seguin N, Chanez P, et al. c-Fos proto-oncogene expression in bronchial biopsies of asthmatics. Am J Respir Cell Mol Biol 1992; 7: 128-133.

62. Ponta H, Cato ACB, Herrlick P. Interference of specific transcription factors. Biochim Biophys Acta 1992; 1129: 255-261.

63. Kishimoto T, Taga T, Akira S. Cytokine signal transduction. Cell 1994; 76: 253-262.

64. Gosset P, Tsicopoulos A, Wallaert B, Vannimenus C, Joseph M, Tonnel AB, Capron A. Increased secretion by tumor necrosis factor $\alpha$ and interleukin 6 by alveolar macrophages consecutive to the development of the late asthmatic reaction. J Allergy Clin Immunol 1991; 88: 561-571.

65. Gosset P, Tsicopoulos A, Wallaert B, Vannimenus C, Joseph M, Tonnel AB, Capron A. Tumor necrosis factor $\alpha$ and interleukin- 6 production by human mononuclear phagocytes from allergic asthmatics after IgE-dependent stimulation. Am Rev Respir Dis 1992; 146: 768-774.

66. Grunberg K, Smits HH, Timers MC, et al. Experimental rhinovirus 16 infection. Effects on cell differentials and soluble markers in sputum in asthmatic subjects. $A m J$ 
Respir Cnt Care Med 1997; 156: 609-616.

67. Darnell JE, Kerr IM, Stark GR. Jak-STAT pathways and transcriptional activation in response to IFNs and other extracellular signalling proteins. Science 1994; 264: 14151421.

68. Ihle JN, Witthuhn BA, Quelle FW, et al. Signalling by the cytokine receptor superfamily: JAKs and STATs. Trends Biochem Sci 1994; 19: 222-225.

69. Ihle JN. Janus kineses in cytokine signalling. Phil Trans $R$ Soc Lond B Biol Sci 1996; 351: 159-166.

70. Battacharya S, Eckner R, Grossman S, Oldread E, Arany Z, D'Andrea A, Livingston DM. Cooperation of Stat2 and p300/CBP in signalling induced by interferon- $\alpha$. Nature 1996; 383: 344-347.

71. Zhang JJ, Vinkemeier U, Gu W, Chakravarti D, Horvath CM, Damell JE. Two contact regions between STAT1 and CBP/p300 in interferon- $\gamma$ signalling. Proc Natl Acad Sci USA 1996; 93: 15092-15096.

72. Hou J, Schindler U, Henzel WJ, Ho TC, Brasseur M, McKnight SL. An interleukin-4-induced transcription factor: IL-4 stat. Science 1994; 265: 1701-1706.

73. Takeda K, Tanaka T, Shi W, et al. Essential role for Stat6 in IL-4 signalling. Nature 1996; 380: 627-630.

74. Kaplan MH, Schindler U, Smiley ST, Grusby MJ. Stat6 is required for mediating responses to IL-4 and for the development of Th2 cells. Immunity 1996; 4: 313-319.

75. Bacon CM, Petricoin EF, Ortaldo JR, et al. IL-12 induces tyrosine phosphorylation and activation of STAT-4 in human lymphocytes. Proc Natl Acad Sci USA 1995; 92: 7303-7311.

76. Kaplan MH, Sun Y, Hoey T, Grusby MJ. Impaired IL-12 responses and enhanced development of Th2 cells in Stat4-deficient mice. Nature 1996; 382: 174-177.

77. Pazdrak K, Stafford S, Alam R. The activation of the Jak-STAT 1 signalling pathway by IL-5 in eosinophils. $J$ Immunol 1995; 155: 397-402.

78. van der Bruggen T, Caldenhoven E, Kanters D, et al. Interleukin-5 signaling in human eosinophils involves JAK2 tyrosine kinase and Stat1a. Blood 1995; 85: 14421448.

79. Mui ALF, Wakao H, O'Farrell AM, Miyaiima A. Interleukin-3, granulocyte-macrophage colony stimulating factor and interleukin-5 transduce signals through two STATS homologs. EMBO J 1995; 14: 1166-1175.

80. Naka T, Narazaki M, Hirata M, et al. Structure and function of a new STAT-induced STAT inhibitor. Nature 1997; 387: 924-929.

81. Starr R, Willson TA, Viney EM, et al. A family of cytokine-inducible inhibitors of signalling. Nature 1997; 387: 917-921.

82. Yamamoto KK, Gonzalez GA, Biggs WH, Montminy MR. Phosphorylation-induced binding and transcriptional efficacy of nuclear factor CREB. Nature 1988; 334: 494-498.

83. Chrivia JC, Kwok RPS, Lamb N, Hagiwara M, Montminy MR, Goodman RH. Phosphorylated CREB specifically binds to the nuclear factor CBP. Nature 1993; 365: 855859.

84. Collins S, Altschmied J, Herbsman O, Caron MG, Mellon PL, Lefkowitz RJ. A cAMP element in the $\beta_{2}$-adrenergic receptor gene confers autoregulation by cAMP. $J$ Biol Chem 1990; 265: 19930-19935.

85. Peters MJ, Adcock IM, Brown CR, Barnes PJ. $\beta$-Adrenoceptor agonists interfere with glucocorticoid receptor DNA binding in rat lung. Eur J Pharmacol 1995; 289: 275281.

86. Nishikawa M, Mak JCW, Shirasaki H, Barnes PJ. Differ- ential down-regulation of pulmonary $\beta_{1}$ - and $\beta_{2}$-adrenoreceptor messenger RNA with prolonged in vivo infusion of isoprenaline. Eur J Pharmacol 1993; 247: 131-138.

87. Mak JCW, Nishikawa M, Shirasaki H, Miyayasu K, Barnes PJ. Protective effects of a glucocorticoid on down-regulation of pulmonary $\beta_{2}$-adrenergic receptors in vivo. J Clin Invest 1995; 96: 99-106.

88. Masquilier D, Sassone-Corsi P. Transcriptional cross talk: nuclear factors CREM and CREB bind to AP-1 sites and inhibit activation by Jun. J Biol Chem 1992; 267: 2246022466.

89. Imai F, Minger JN, Mitchell JA, Yamamoto KR, Granner DK. Glucocorticoid receptor-cAMP response elementbinding protein interaction and the response of the phosphoenolpyruvate carboxykinase gene to glucocorticoids. J Biol Chem 1993; 268: 5353-5356.

90. Stevens DA, Barnes PJ, Adcock IM. $\beta$-Agonists inhibit DNA binding of glucocorticoid receptors in human pulmonary and bronchial epithelial cells. Am J Respir Crit Care Med 1995; 151: A195.

91. Adcock IM, Stevens DA, Barnes PJ. Interactions between steroids and $\beta_{2}$-agonists. Eur Respir J 1996; 9: 160-168.

92. Janknecht R, Hunter T. A growing coactivator network. Nature 1996; 383: 22-23.

93. Arias J, Alberts AS, Brindle P, et al. Activation of cAMP and mitogen responsive genes relies on a common nuclear factor. Nature 1994; 370: 226-229.

94. Kamei Y, Xu L, Heinzel T, et al. A CBP integrator complex mediates transcriptional activation and AP-1 inhibition by nuclear receptors. Cell 1996; 85: 403-414.

95. Perkins ND, Feizien LK, Betts JC, Leung K, Beach DH, Nabel GJ. Regulatioj of NF- $\kappa \mathrm{B}$ by cyclin-dependent kineses associated with the p300 coactivator. Science 1997; 275: 523-526.

96. Smith CL, Onate SA, Tsai MJ, O'Malley BW. CREB binding protein acts synergistically with steroid receptor coactivator-1 to enhance steroid receptor-dependent transcription. Proc Natl Acad Sci USA 1996; 93: 8884-8888.

97. Yao PM, Buhler JM, D'Ortho MP, Lebargy F, Delclaux C, Harf A, Lafuma C. Expression of matrix metalloproteinase gelatinases A and B by cultured epithelial cells from human bronchial explants. J Biol Chem 1996; 271 : 15580-15589.

98. Hong H, Kohli K, Garabedian MJ, Stallcup MR. GRIP1, a transcriptional coactivator for the AF-2 transactivation domain of steroid, thyroid, retinoid, and vitamin D receptors. Mol Cell Biol 1997; 17: 2735-2744.

99. Torchia J, Rose DW, Inostroza J, Kamei Y, Westin S, Glass CK, Rosenfeld MG. The transcriptional co-activator $\mathrm{p} / \mathrm{CIP}$ binds CBP and mediates nuclear receptor function. Nature 1997; 387: 677-684.

100. Heery DM, Kalkhoven E, Hoare S, Parker MG. A signature motif in transcriptional co-activators mediates binding to nuclear receptors. Nature 1997; 387: 733-736.

101. Ogryzko W, Schiltz RL, Russanova V, Howard BH, Nakatani Y. The transcriptional coactivators p300 and CBP are histone acetyltransferases. Cell 1996; 87: 953959.

102. Wolffe AP. Sinful repression. Nature 1997; 387: 16-17.

103. Nagy L, Kao HY, Chakravarti D, et al. Nuclear receptor repression mediated by a complex containing SMRT, mSin3A, and histone deacetylase. Cell 1997; 89: 373380.

104. Heinzel T, Lavinsky RM, Mullen TM, et al. A complex containing N-CoR, mSin 3 and histone deacetylase mediates transcriptional repression. Nature 1997; 387: 43-48.

105. Adcock IM, Gilbey T, Gelder CM, Chung KF, Barnes PJ. 
Glucocorticoid receptor localization in normal human lung and asthmatic lung. Am J Respir Crit Care Med 1996; 154: 771-782.

106. Truss M, Beato M. Steroid hormone receptors: interaction with deoxyribonucleic acid and transcription factors. Endocr Rev 1993; 14: 459-479.

107. Mak JCW, Grandordy B, Barnes PJ. High affinity $\left[{ }^{3} \mathrm{H}\right]$ formoterol binding sites in lung: characterization and autoradiographic mapping. Eur J Pharmacol 1994; 269: $35-41$.

108. Barnes PJ. Mechanism of action of glucocorticoids in asthma. Am J Respir Crit Care Med 1996; 154: S21-S27.

109. Scheinman RI, Cogswell PC, Lofquist AK, Baldwin AS. Role of transcriptional activation of $\mathrm{I} \kappa \mathrm{B} \alpha$ in mediating immunosuppression by glucocorticoids. Science 1995; 270: 283-286.

110. Brostjan C, Anrather J, Csizmadia V, Stoka D, Soares M, Bach FH, Winkler H. Glucocorticoid-mediated repression of NKKB activity in endothelial cells does not involve induction of IкB $\alpha$ synthesis. J Biol Chem 1996; 271: 19612-19616.

111. Newton R, Hart LA, Adcock IM, Barnes PJ. Effect of glucocorticoids on IL- $1 \beta$-induced NF- $\kappa B$ binding and expression in type II alveolar cells - no evidence for downregulation by IкB. Am J Respir Crit Care Med 1997.

112. Heck S, Bender K, Kullmann M, Gottlicher M, Herrlich $\mathrm{P}$, Cato AC. IKB alpha-independent downregulation of NF- $\kappa B$ activity by glucocorticoid receptor. EMBO J 1997; 16: 4698-4707.

113. Barnes PJ, Adcock IM. Anti-inflammatory actions of steroids: molecular mechanisms. Trends Pharmacol Sci 1993; 14: 436-441.

114. Ray A, Prefontaine KE. Physical association and functional antagonism between the p65 subunit of transcription factor NF- $\mathrm{KB}$ and the glucocorticoid receptor. Proc Natl Acad Sci USA 1994; 91: 752-756.

115. Caldenhoven E, Liden J, Wissink S, et al. Negative cross-talk between RelA and the glucocorticoid receptor: a possible mechanism for the antiinflammatory action of glucocorticoids. Mol Endocrinol 1995; 9: 401-412.

116. Stocklin E, Wissler M, Gouilleux F, Groner B. Functional interactions between Stats and the glucocorticoid receptor. Nature 1996; 383: 726-728.

117. Kleinert H, Euchenhofer C, Ihrig Biedert I, Forstermann U. Glucocorticoids inhibit the induction of nitric oxide synthase II by down-regulating cytokine-induced activity of transcription factor nuclear factor- $\mathrm{\kappa B}$. Mol Pharmacol 1996; 49: 15-21.

118. Saleh D, Ernst P, Barnes PJ, Giaid A. Increased formation of the potent oxidant peroxynitrate in the airways of asthmatics. Effect of inhaled glucoccorticoid. Am J Respir Crit Care Med 1998; 157: A871.

119. Kharitonov SA, Yates D, Barnes PJ. Increased nitric oxide in exhaled air of normal human subjects with upper respiratory tract infections. Eur Respir J 1995; 8: 295-297.

120. Kuo H, Barnes PJ, Rogers DF. Cigarette smoke-induced airway goblet cell secretion: dose dependent differential nerve activation. Am J Physiol 1992; 7: L161-L167.

121. Berkman N, Robichaud A, Krishnan VL, Barnes PJ, Chung KF. Expression of RANTES in human airway epithelial cells: effect of corticosteroids and interleukins-4, 10 and 13. Immunology 1996; 87: 599-603.

122. Wang JH, Devalia JL, Xia C, Sapsford RJ, Davies RJ. Expression of RANTES by human bronchial epithelial cells in vitro and in vivo and the effect of corticosteroids. Am J Respir Cell Mol Biol 1996; 14: 27-35.

123. Barnes PJ, Adcock IM. Steroid-resistant asthma. $Q J$ Med
1995; 88: 455-468.

124. Barnes PJ, Greening AP, Crompton GK. Glucocorticoid resistance in asthma. Am J Respir Crit Care Med 1995; 152: 125S-140S.

125. Szefler SJ, Leung DY. Glucocorticoid-resistant asthma: pathogenesis and clinical implications for management. Eur Respir J 1997; 10: 1640-1647.

126. Adcock IM, Lane SJ, Brown CA, Peters MJ, Lee TH, Barnes PJ. Differences in binding of glucocorticoid receptor to DNA in steroid-resistant asthma. J Immunol 1995; 154: 3000-3005.

127. Adcock IM, Lane SJ, Brown CA, Lee TH, Barnes PJ. Abnormal glucocorticoid receptor/AP-1 interaction in steroid resistant asthma. J Exp Med 1995; 182: 1951-1958.

128. Adcock IM, Lane SJ, Barnes PJ, Lee TH. Enhanced phorbol ester-induced c-Fos transcription and translation in steroid-resistant asthma. Am J Respir Crit Care Med 1996; 153: A682.

129. Adcock IM, Brady H, Lim S, Karin M, Barnes PJ. Increased JUN kinase activity in peripheral blood monocytes from steroid-resistant asthmatic subjects. Am J Respir Crit Care Med 1997; 155: A288.

130. Lane SJ, Atkinson BA, Swimanathan R, Lee TH. Hypothalamic-pituitary axis in corticosteroid-resistant asthma. Am J Respir Crit Care Med 1996; 153: 15101514.

131. Shibasaki F, Price ER, Milan D, McKeon F. Role of kineses and the phosphatase calcineurin in the nuclear shuttling of transcription factor NF-AT4. Nature 1996; 382: 370-373.

132. Hoey T, Sun YL, Williamson K, Xu X. Isolation of two new members of the NF-AT gene family and functional characterization of the NF-AT proteins. Immunity 1995; 2: 461-472.

133. Jain J, McCaffrey PG, Valge Archer VE, Rao A. Nuclear factor of activated $\mathrm{T}$ cells contains Fos and Jun. Nature 1992; 356: 801-804.

134. Northrop JP, Ullman KS, Crabtree GR. Characterization of the nuclear and cytoplasmic components of the lymphoid-specific nuclear factor of activated T cells (NFAT). J Biol Chem 1993; 268: 2917-2923.

135. Palmer JBD, Cuss FMC, Mulderry PK, et al. Calcitonin gene-related peptide is localized to human airway nerves and potently constricts human airway smooth muscle. $\mathrm{Br}$ J Pharmacol 1987; 91: 95-101.

136. Wright LC, Cammisuli S, Baboulene L, Fozzard J, Adcock IM, Barnes PJ. Cyclosporin A and glucocorticoids interact synergistically in T lymphocytes: implications for asthma therapy. Am J Respir Crit Care Med 1995; 151: A675.

137. Lee HJ, Matsuda I, Naito Y, Yokota T, Arai N, Arai K. Signals and nuclear factors that regulate the expression of interleukin-4 and interleukin-5 genes in helper T cells. $J$ Allergy Clin Immunol 1994; 94: 594-604.

138. Hodge MR, Rooney JW, Glimcher LH. The proximal promoter of the IL-4 gene is composed of multiple essential regulatory sites that bind at least two distinct factors. J Immunol 1995; 154: 6397-6405.

139. Hodge MR, Ranger AM, Charles de la Brousse F, Hoey T, Grusby MJ, Glimcher LH. Hyperproliferation and dysregulation of IL-4 expression in NF-ATp-deficient mice. Immunity 1996; 4: 397-405.

140. Hodge MR, Chun HJ, Rengarajan J, Alt A, Lieberson R, Glimcher LH. NF-AT-Driven interleukin-4 transcription potentiated by NIP45. Science 1996; 274: 1903-1905.

141. Lee HJ, Masuda ES, Arai N, Arai K, Yokota T. Definition of cis-regulatory elements of the mouse interleukin-5 
gene promoter. Involvement of nuclear factor of activated $\mathrm{T}$ cell-related factors in interleukin-5 expression. $J$ Biol Chem 1995; 270: 17541-17550.

142. Prieschl EE, Gouilleux Gruart V, Walker C, Harrer NE, Baumruker T. A nuclear factor of activated T cell-like transcription factor in mast cells is involved in IL-5 gene regulation after IgE plus antigen stimulation. $J$ Immunol 1995; 154: 6112-6119.

143. Mori A, Kaminuma O, Suko M, et al. Two distinct pathways of interleukin-5 synthesis in allergenspecific human T-cell clones are suppressed by glucocorticoids. Blood 1997; 89: 2891-2900.

144. Manning AM. Transcription factors: a new frontier in drug discovery. Drug Dev Ther 1996; 1: 151-160.

145. Heck S, Kullmann M, Grast A, Ponta H, Rahmsdorf HJ, Herrlich P, Cato ACB. A distinct modulating domain in glucocorticoid receptor monomers in the repression of activity of the transcription factor AP-1. EMBO J 1994; 13: 4087-4095.

146. Adcock IM, Barnes PJ. Ligand-induced differentiation of glucocorticoid recepotpr (GR) transrepression and transactivation. Am J Respir Crit Care Med 1996; 153: A243.

147. Vayssiere BM, Dupont S, Choquart A, et al. Synthetic glucocorticoids that dissociate transactivation and AP-1 transrepression exhibit antiinflammatory activity in vivo. Mol Endocrinol 1997; 11: 1245-1255.

148. Barnes PJ, Adcock IM. NF-אB: a pivotal role in asthma and a new target for therapy. Trends Pharmacol Sci 1997; 18: $46-50$.

149. Miyajima T, Kotake Y. Spin trapping agent, phenyl $\mathrm{N}$-tert-butyl nitrone, inhibits induction of nitric oxide synthase in endotoxin-induced shock in mice. Biochem Biophys Res Commun 1995; 215: 114-121.

150. Pahl HL, Krauss B, Schultze-Osthoff K, et al. The immunosuppressive fungal metabolise gliotoxin specifically inhibits transcription factor NF-кB. J Exp Med 1996; 183: 1829-1840.

151. Wang P, Wu P, Siegel Ml, Egan RW, Billah MM. Interleukin( $(\mathrm{L})-10$ inhibits nuclear factor $\kappa \mathrm{B}$ activailon in human monocytes. IL-10 and IL-4 suppress cytokine synthesis by different mechanisms. J Biol Chem 1995; 270: 9558-9563.

152. John M, Lim S, Seybold J, Robichaud A, O'Connor B, Barnes PJ, Chung KF. Inhaled corticosteroids increase IL-10 but reduce MIP- $1 \alpha$, GM-CSF and IFN- $\gamma$ release from alveolar macrophages in asthma. Am J Respir Crit Care Med 1998; 157: 256-262.

153. Yaron A, Gonen H, Alkalay I, et al. Inhibition of NF-אB cellular function via specific targeting of the IKB-ubiquitin ligase. EMBO J 1997; 16: 6486-6494.

154. Wrighton CJ, Hofer-Warbinek R, Moll T, Eytner R, Bach $\mathrm{FH}$, de Martin R. Inhibition of endothelial cell activation by adenovirus-mediated expression of $\mathrm{I} \kappa \mathrm{B} \alpha$, an inhibitor of transcription factor NF-кB. J Exp Med 1996; 183: 1013-1022.

155. Wallace J, Adcock IM, Barnes PJ. Retinoic acid potentiates the inhibitory effects of dexamethasone on AP-1 DNA binding in epithelial cells. Am J Respir Crit Care Med 1996; 153: A209

156. Rowe A. Retinoid X receptors. Int J Biochem Cell Biol 1997; 29: 275-278. 